\title{
The University of Zambia School Teaching Experience: Is It Effective?
}

\author{
Peter Chomba Manchishi ${ }^{\mathrm{a}}$ and David Sani Mwanza ${ }^{\mathrm{a},{ }^{*}}$ \\ ${ }^{a}$ University of Zambia, Zambia
}

\begin{abstract}
Teaching practice exercises serve the purpose of orienting the teacher into real classroom situations where the novice puts his or her skills into practice. Education students at the University of Zambia (UNZA) go through the school teaching experience after their third year of study. This comes after they have arguably completed enough content and methodology courses to teach. The purpose of this study was to establish the effectiveness of the UNZA school teaching experience. The research instruments used were interview guides, observation checklists, and focus group discussions. The respondents included 80 serving teachers, 80 student teachers, and 10 head teachers drawn from 10 high schools in the Lusaka District. In addition, 10 lecturers from UNZA were also sampled. The findings revealed that the design and delivery of the UNZA student teaching experience was not effective.
\end{abstract}

\begin{abstract}
Abstrak
Latihan praktek mengajar bertujuan memberikan orientasi bagi guru pemula sehingga mereka dapat mengaplikasikan ketrampilannya di ruang kelas sesungguhnya. Mahasiswa Fakultas Pendidikan Universitas Zambia (UNZA) menjalani praktek mengajar pada tahun keempat; setelah mereka mendapatkan materi kuliah yang cukup mengenai bahan ajar dan metodologi pembelajarannya. Artikel ini bertujuan mengukur efektitivitas program praktek mengajar yang diselenggarakan UNZA. Instrumen yang digunakan dalam penelitian ini terdiri dari panduan wawancara, checklist observasi, dan focus group discussions. Responden penelitian ini meliputi 80 guru, 80 mahasiswa yang sedang menjalani praktek mengajar, dan 10 guru kepala yang tersebar di 10 sekolah menengah di Distrik Lusaka. Selain itu, data juga didapatkan dari 10 dosen Fakultas Pendidikan UNZA. Penelitian ini menyimpulkan bahwa desain dan pelaksanaan praktek mengajar tersebut tidak efektif.
\end{abstract}

Key Words: School Teaching Experience, Zambia, Teacher Training, Student Teaching, Higher Education

\section{Introduction}

Teaching practice is one of the most important components of teacher training. According to Frank Youngman (1995), teaching practice can be viewed from a philosophical point of view, in terms of the relationship between theory and practice. Furthermore, it can also be viewed sociologically in terms of the tension between the tendency for the training

* Corresponding author.

Email: sanidavidmwanza@yahoo.com institutions to advocate innovation and experimentation and the tendency for the schools to be preoccupied with day-to-day operation and routines. It appears therefore that teaching practice socializes students into the teaching profession. Also, teaching practice can be viewed from a pedagogical point of view in terms of how to prepare students in advance for their school experience and how to supervise it and follow it up in a way that leads to maximum learning and personal development. In addition, it can be considered from an organizational point of view in terms of the logistics of placing students, the transportation of staff, the costs, and so on. 
R. Mulomo (1990) observed that teaching practice is part of teacher preparation. It is the dynamic phase of teacher preparation because the student teacher is provided with the opportunity to apply the theoretical learning that has been taught throughout the teacher preparation program in a real situation. It is not possible to separate teaching practice from teacher preparation. This is because teaching practice is an integral part of teacher preparation programs.

\section{The Purpose of the Teaching Experience}

The teaching practice exercise serves the purpose of orienting the teacher into the real world of classroom teaching. Teaching practice sees the novice putting his or her skills into practice and behaving in a normal school situation before he or she graduates from the School of Education to start practicing as a teacher (Chakalisa 1990).

According to the University of Zambia (UNZA) School of Education guidelines, the teaching practice enables students to:

1. Observe qualified and experienced teachers;

2. Relate aspects of the university courses to the classroom situation;

3. Apply the basic sticks of planning, preparing, and presenting suitable materials to meet the needs of their classes;

4. Develop organizational skills and self-confidence; and

5. Establish good working relationships with pupils and teachers.

\section{Problem Statement}

The teaching practice exercise serves the purpose of orienting the teacher into a real classroom situation where the novice puts his or her skills into practice and behaves normally in a normal school situation. However, since no comprehensive study has been done on the UNZA school teaching experience, there was no way to judge its effectiveness; we did not know whether or not it was fulfilling the practicum goals.

\section{Purpose of Study}

The purpose of this study was to establish the effectiveness of UNZA school teaching experience.

The study sought to address eight objectives. Since, to date, there has not been a comprehensive study completed on the UNZA teaching experience, the objectives were designed to touch on all the important aspects of the student teaching experience. In addition, the objectives sought information that was qualitative in nature.

The study intended to establish:

1. The effectiveness of the school experience;

2. Student teachers' expectations from the school experience;

3. Student teachers' expectations from school experience supervisors (lecturers);

4. Student teachers' expectations from the cooperating schools;

5. UNZA lecturers' views on the school experience;

6. Cooperating partners' views on the school experience;

7. Whether the instruction, including content and methodology, student teachers receive from UNZA is adequate to prepare them for the school experience; and

8. The challenges faced in the design and delivery of the school experience.

\section{Literature Review}

According to Cosmas Cobbold (2011), professional experience is a period in schools where the prime focus for the trainee teacher is to practice teaching under the supervision of a mentor. The mentor should be trained to understand the range of tasks that make up the student teacher's role, including planning, assessing, and reporting.

During the teaching practicum, pre-service teachers learn to teach by means of the personal experience they get in the field (Munby et al. 2001; Britzman 2003). They fully appreciate the craft, professional demands and dimensions of teaching, learn the realities of day-to-day teaching in a real 
classroom, and simultaneously learn to put pedagogical theory into practice. As the bridge between theory and practice, the practicum also provides the context in which pre-service teachers develop a personal teaching competence (Smith and Lev-Ari 2005).

In other words, during practicum, pre-service teachers learn from experience, which prepares them for the full scope of the teacher's role, for accomplishing the central purposes of schooling with all students, and for developing the ability and disposition to keep on growing (Zeichner 1996). Preservice teachers' experiences in the schools also shape their conception about teaching and learning in school contexts, as well as their attitudes toward their work and the children they teach (Hodge et al. 2002).

According to guidelines prepared by Queensland College (2011), professional experience provides an important avenue through which pre-service teachers develop and demonstrate the graduate standards. Professional experience should be tightly integrated with institution-based leaning. Teacher education institutions and professional experience sites share responsibility for the professional component of teacher education. The institution is responsible for the arrangement of practical experience placements, the preparation of students for practical experience, the support students receive during the placement, and the provision of additional support for schools and supervising teachers.

It is important to note that the professional experiences provided during the program should be of sufficient length to enable all students to develop the required knowledge, skills, and attributes, and to provide adequate opportunities for students to demonstrate attainment of these against the standards. Richard K. Coll and Karsetn E. Zegwaard (2006) agree that if students are to develop enthusiasm and be acculturated into their chosen profession, then they need to spend more time in communities of practice, such as schools. David Boud, Nicky Solomon, and Colin Symes (2001) caution, however, that while spending considerable time in the workplace provides opportunities, it also presents considerable challenges for learners.
According to Lorraine Harrison (2004), students are required to spend a minimum of 18 weeks in school and experience two significant placements (in two different schools). The school-based elements of the course provide the context where students are able to demonstrate all aspects of their professional competence. In addition, the School of Education should establish a strong (and continually developing) partnership with schools in the region in order to ensure that appropriate procedures are put in place that enable students to develop appropriate expertise as teachers.

Jeanne Maree Allen and Deborah Peach (2007) observed that one of the major and long standing challenges of pre-service teacher education programs has been to strike a balance between the theory and practice of the profession.

According to Deborah Britzman (2003), the disconnection between the field and on-campus components of pre-service programs can result in a devaluing by pre-service teachers of aspects of their theoretical learning.

The "gap" between the realities of teaching and taking on-campus courses becomes evident from the first practice teaching session undertaken by pre-service teachers (Smith and Moore 2006). It is little wonder then, as identified by Fred Korthagen, John Loughran, and Tom Russell (2006), that the evidence suggests that when making instructional decisions, teachers tend to devalue and, in many cases, rarely draw upon the kind of theory that is presented to them in their pre-service training. Allen and Peach (2007) noted that in Africa, it appears no deliberate attempt is made to link theory and practice in how the practicum is planned and administered. Therefore, pre-service teachers rarely see the connection between the practical and the theoretical components of teacher education undertaken in colleges or universities.

Commenting on the link between theory and practice in pre-service teacher education, Lawrence Ingvarson, Adrian Beavis, Elizabeth Kleinhenz, and Allison Elliott (2004) revealed that "many respondents viewed the theory-practical question from the application approach. The preparation of teachers was linked to the constructivist perspective 
that encouraged students to build their own personal theory and philosophy of teaching through learning how to analyze and evaluate their practice." The question therefore is whether the UNZA encourages a reflective pedagogy during the school teaching experience of its students.

On the role of training institutions in teacher preparation, Edward R. Ducharme and Mary K. Ducharme (2005) observed that teaching has not improved because teacher educators, frankly, are limited in their pedagogical abilities, and no major pressures exist to change the nature of their teacher education. College classrooms are truly private sanctuaries. These fundamental problems of pedagogy, underestimated by most and ignored by many in the teacher education literature, are nonetheless manifest everywhere. They speak both to how educators have failed to authentically engage many bright and materially rich student teachers in their formal schooling as well as the problem of educating our equally able but less supported youngsters who live in conditions of poverty. The perception is that most teacher educators in the teacher education community do not know how to proceed in terms of adapting teacher education programs to meet the demands of the new pedagogical challenges.

Emphasizing the importance of pre-service teacher education, S.K. Gandhe $(2010,10)$ stated, "[the] professional model is based on the principle of matching academic or subject knowledge and professional competencies. Future teachers are expected to be provided with instructional skills and knowledge of pupils and leaning practices and child development." The findings and discussion of the study will answer the question of whether the UNZA is effectively achieving this aim.

Even though the responsibility of teacher preparation largely rests on the training institutions, Lee Jerome, Jeremy Hayward, and Helen Young (2003) believe that teachers should assume the responsibility for personal professional development. A teacher should feel that he or she owes it to himself or herself and the pupils to continually develop professionally. A teacher should work hard at becoming the teacher he or she wants to be. This is also the way in which a teacher can ensure that his or her career works out the way he or she wants. Different skills will need to be developed, and different opportunities will need to be planned for. This means that student teachers should not blame their inabilities or inadequacies on the teacher educators, because they can also contribute to self-professional development outside the lecture room.

In addition to the argument above, Charlotte Danielson (2008) noted that the first, and in some respects the most important, contributor to professional learning is a culture of inquiry. It is essential that all educators recognize that the work of professional learning never ends; it is a career-long endeavor. When school leaders (both teachers and administrators) insist that it is part of every teacher's responsibility to engage in professional development, this is not to suggest that teachers, either individually or collectively, are deficient in their practice. Rather, it is to maintain that teaching is so complex that it is never done perfectly; every educator can always become more skilled, more expert. Moreover, making a commitment to do so is part of the essential work of teaching. It is not an add-on, an extra; rather, it is integral to that work. From this argument, it appears that it is not fair to expect student teachers to be perfect in the way they handle classes and other school duties during the practicum, because learning or becoming a good teacher is a never-ending process. However, student teachers should still be able to demonstrate the most basic and essential qualities of a teacher during the practicum.

The school teaching experience faces several challenges in both design and delivery. For example, there is normally a lack of communication between University supervisors and the student teachers. Sometimes, neither the student nor the University supervisor know when visitations should occur. Allen and Peach (2007) established that both student teachers and school supervisors felt lost and unsure of when a university representative would make contact. One student said:

The university representative called the third last day of my practical which we saw as useless because I had already been there for three and a half weeks without contact. 
Another participant claimed that both the student teacher and the classroom teacher were unsure of what was expected and suggested that more time could have been spent at university being "instructed or shown through the practical book more thoroughly."

The design and delivery of the practicum includes the timing of the practicum in relation to the high school calendar. Studies both in Africa and elsewhere have shown that in many instances, the timing of the practicum does not allow pre-service teachers to experience school settings from the first day of the new academic year. This is common in Western models as well. The reason for this is partially due to huge differences in dates for commencing and ending the academic year for schools, colleges, and universities. As a result, schools find it challenging to take on pre-service teachers during this busy time. In addition, colleges and universities do not prioritize the "time-tabling" of their courses in relation to the high school calendar. Whatever the reason, the timing of the practicum denies preservice teachers the "invaluable opportunity to experience the process of setting up a new classroom and how relationships are formed with new groups of school children" (Cobbold 2011, 47).

Magdeline C. Mannathoko (1990) conducted a study on the coordination of teaching practice in secondary schools in Botswana. She wanted to find out various aspects of coordination and the challenges encountered. The study revealed that channels of communication needed to be improved on. She noted that while the School of Education held seminars to discuss teaching practice issues, these seminars were not held regularly. In addition, the study showed that channels of communication between university coordinators and the schools were very weak; there was a need for a more structured program for working with schools and developing a rapport with school head teachers. Further, the number of student teachers who went for teaching practice increased every year. This posed a challenge on coordination of teaching practice.

M. Lecha (1999) conducted another study that investigated some practical issues about teacher preparation. The study revealed that in terms of teaching methodology, the common criticism in Botswana is that the initial training of teachers is dry, inadequate, and removed from the practical realities of the school situation.

Commenting on the above findings, Lecha (1999) added that even though the program of teacher preparation at college is not ideal, many critical voices are often heard about the shallow nature of the instruction, especially in providing useful practical experience to the trainees. It was argued that while simulation exercises, such as peer teaching and micro-teaching, were a useful part of teacher preparation, they still lacked the value of a real life teaching experience. Lecha's observation implies that it is not only the school teaching experience that is shallow but also the instructions that are received from the teacher training institution before entering the classroom.

Peter Chomba Machishi and Gift Masaiti (2011) conducted a study to find out if UNZA pre-school teacher programs were responsive to the aspirations of schools and communities. The findings indicated that there were gaps between what the UNZA was offering and what was being obtained in schools. The study further noted that trainee teachers were exposed to broad content material, which in some cases did not take into consideration what was being taught in Zambian high schools. This is in agreement with Lawrence Musonda (1995) who noted that one of the problems linked to the school experience was that what goes on in universities and colleges is sometimes not what the student teachers meet in schools where they go to teach. Another finding that came out of Manchishi and Masaiti's (2011) study was that there was inadequate preparation for trainee teachers in the social aspect of the teaching professional, such as school community partnerships, and there was equally inadequate preparation of trainee teachers with knowledge and skills to adapt to change in the classroom. In view of the findings, the study recommended that there was a need for all stakeholders involved in teacher preparation to come together and re-examine the teacher training programs offered at UNZA.

Hugh T. Sockett and colleagues (2001) observed that the history of teacher education has pressed 
forward by establishing a lamentable and growing distance from moral thought. Young teachers are believed to be hungry for technique, yet their motivation is strong and idealistic. Teacher education as presently constructed can answer neither of these interests. It cannot equip young teachers with classroom skills because the complexities of the classroom change. Present teacher education cannot give young students a moral education, for it has neglected the moral framework within which "a sense of calling" (and much else) can be examined. Sockett and colleagues (2001) therefore suggest that there is need for teacher training institutions to collaborate with communities and families in the preparation of educators if student teachers and classroom teachers are to respond to the aspirations of the community.

Manchishi (2013) added another weakness of UNZA when he stated that student teachers were observed only once during the practicum, which was not adequate. It was emphasized that one observation was not a fair way of appraising classroom performance. Therefore, more observations were needed to have a reliable and valid assessment. What worsened the situation was that the teaching experience was not graded; hence, students did not take the practicum seriously.

In conclusion, it has been observed through the literature that there is a gap between what students learn in pre-service training (theory) and what they are supposed to teach in real classroom situations (practice). Studies have also shown that in many countries, micro-teaching and peer teaching skills obtained during on-campus training were not adequate to prepare them for the practicum or teaching in normal classroom situations.

\section{Research Design and Methodology}

\section{Research Design}

This study employed a case study design. A case study may be of one person, class, district, country, continent or family. Therefore, this study qualifies as a case study because it drew its respondents from the Lusaka District only.

\section{Sample Size and Sampling Techniques}

By definition, a sample is the segment of the population that is selected for investigation. In this study, the sample was comprised of 10 high schools. In terms of the teachers, the sample had 80 respondents; eight from each school with equal distribution of gender. Ten head teachers, one from each school also formed part of the sample. In terms of gender at each school, three were female while seven were male. Ten lecturers, four of whom were female, from the UNZA School of Education were sampled.

There were challenges associated with the respondents. For example, some teachers refused to be interviewed and kept on postponing the appointment for the interview. As a result, data collection took longer than expected as the researcher visited some individual respondents more than once. Regarding lecturers, the study intended to interview 16 lecturers with a representation of two lecturers from each department in the School of Education. However, only 10 lecturers out of the targeted 16 were interviewed. The reason was that the other six claimed to have been busy and that they could not find time for the interview. Some of the respondents (among the 10) postponed the appointment more than once before they finally made themselves available for the interview.

Both simple random and purposive sampling techniques were used. According to C.J. White (2003), the simple random technique is a selection technique that provides each population element with an equal chance of being included in the sample. In this study, simple random sampling was used to come up with the 10 schools. This was done by getting an inventory of all the high schools in Lusaka District and conducting a ruffle. The same method was used to come up with the 30 teachers.

Purposive sampling was used to select head teachers in the sampled schools, the lecturers, the standard officers, and the District Education Board Secretary. This was done because these groups of people were all directly involved in the school teaching experience. They needed to be purposively selected so that they could represent the relevant variables in this study. 


\section{Research Instruments}

The instruments used to collect data were focus group discussions and interviews. Focus group discussions were used to solicit answers from the teachers. They were used because the teachers who were sampled were many and they could easily be reached through focus group discussions. An interview guide was used to interview the head teachers, the District Education Board Secretary, the standard officers, and the lecturers from UNZA. An interview guide containing open-ended questions was important as the researcher was able to ask follow up questions and sought clarification where the respondent were not clear.

\section{Data Analysis}

The qualitative approach was used to analyze verbal information that was collected from the focus group discussions and interviews. It must be mentioned that the data was grouped under identified themes guided by research questions and objectives.

\section{Findings}

The findings of this study are presented as responses to eight research questions.

\section{How Effective Is the UNZA School Teaching Experi- ence?}

Some respondents said that the school teaching experience was effective. It helped the student teacher get familiar with the teaching profession. One respondent said that the school teaching experience was effective, especially because student teachers had only practiced teaching during peer teaching. One female (teacher) respondent said:

It is effective because it allows one to have the feel of [the] classroom situation and has challenged or approved the validity of theoretical knowledge. School teaching practice is very effective because it helps to build up confidence in student teachers who have never taught in schools before. In addition, it also helps student teachers develop a positive attitude towards the teaching profession.

Although some respondents were of the view that the school teaching experience was effective as stated above, most of them had an opposing view. They believed that the school teaching experience was not effective. Some respondents out rightly pointed out that UNZA school teaching practicum was not effective because it was too short and students did not receive help from lecturers or cooperating schools. In addition, the practicum was not graded thereby rendering it irrelevant. They added that having the practicum during the student teachers' fourth year was not appropriate. One male head teacher had the following to say:

I think the student teaching practicum is not effective. I would rate it $5 / 10$ because students are given a period of six weeks, which I think is not adequate enough to prepare someone for the teaching industry. I also think the practicum should be done in the third year the whole of the second semester. After the students do their teaching methods, they should go into real schools to teach for a semester; one term at least. Like this, they will use their skills effectively because they are familiar with them, not teaching in fourth year when students will have forgotten some teaching skills.

From the above findings, it is clear that while some respondents viewed the school teaching experience as effective, most of them asserted that it was not effective.

\section{What Are the Student Teachers' Expectations of the} School Teaching Experience?

Student teachers had several expectations. For example, one male student teacher said:

My expectations of the practicum were to get to an environment where there was a proper interaction between pupils, teachers, and us training teachers. But firstly, there was stereotyping from pupils, 
especially to start with. We were introduced as training teachers, so the pupils held a preconceived mind about us from their past experiences with student teachers; hence, this [generated] their attitude. Secondly, the teachers were suspicious of us, thinking that we had come to take away their jobs, while some just left their classes to us without supervision. But it was fairly good once we became acclimated to the environment.

Several respondents shared the message in the above quote. Most of the respondents, both males and females, observed that they were not professionally treated and they did not receive adequate support from the serving teachers, some of whom were graduates from UNZA.

What Are the Student Teachers' Expectations from the School Experience Supervisors (Lecturers)?

Some respondents said that they expected the lecturers to be available for consultation throughout the teaching practice period. Others said that they expected lecturers to be of help with finances and provide guidelines on how the student teacher should behave during teaching practice. One female student teacher stated:

We expected a lot. We thought that lecturers would help us with teaching materials and to observe us twice and tell us our weaknesses. I expected regular follow-ups, checks if I am facing any challenges. I expected my lecturers to give me guidance on how to go about the process of the practicum. Unfortunately, there was no guidance such that, even when I reported at the school, I did not know what was required from me apart from the teaching and learning taking place in the classroom.

Other than the expectations stated in the above quote, student teachers complained of a lack of effective communication from the lecturers. The lecturers only communicated when they were going to observe the student teacher. Most respondentssome of whom said that they were not given contacts for lecturers who they could call when they had any problems - did not appreciate this.

What Are the Student Teachers' Expectations from the Cooperating Schools?

Some of the respondents said that they expected cordial relationships with the schools. Student teachers said they wanted a lot of professional advice from the serving teachers, which, unfortunately, they did not get. One female respondent asserted:

I have not yet talked to the teachers about my performance, hence I do not know if the expectations were met. I expected them to be more friendly and helpful in terms of writing lesson plans together, but their attitude towards us from some of them left much to be desired. They were a bit hostile and accused us of just distributing their classes because they thought we went to grab their jobs.

Due to the situation as presented above, student teachers reported that they did most of the work on their own without help from either the teachers or the administrators. They stated that most serving teachers were not willing to help as they considered UNZA students as so knowledgeable that they did not need any help.

What Are the Views of the UNZA Lecturers on the School Teaching Experience?

The point of this question was to establish the views of the lecturers on school teaching experience. Most of the respondents said that school teaching experience was not well designed, as it was unpredictable because of certain changes, which are due to disturbances in the academic calendar. Lecturers observed that the UNZA school teaching practice calendar did not conform to the calendar of government secondary schools, including private schools. There is a need to redesign school practice so that it suits the Ministry of Education school calendar. Some lecturers reported that school teaching practice was money oriented. One female lecturer had the following to say: 
Lecturers are not concerned about students' welfare; there is no communication. The only communication is when a lecturer wants to observe. They don't help or communicate with students; they only visit students to observe and make money. I mean, the whole thing is money centered. Because of wanting to observe many students, lecturers observe very brief lessons to accommodate a lot of students. There is no seriousness in observers.

In addition to the above statement, other lecturers stated that some students did not take the school teaching experience seriously because the exercise was not graded. One male lecturer said, "Our students do not read widely, so they cannot improve their teaching beyond what they get from the lecture room."

What Are the Views of the Cooperating Schools on the School Teaching Experience?

All the respondents were unanimous in saying that the period for teaching practice was very short. They stated that students went for six weeks and that before a student settled in a school, lecturers visited the student for observation. They added that the school teaching practice ended at a time when the student teachers were just being settled in the schools and were starting to make meaningful contributions.

The respondents also added that student teachers from UNZA were not adequately trained. They were inadequately prepared in methodology and desirable etiquette. In addition, there were instances where the pupils complained about the improper dressing of the student teachers, especially female student teachers. They added that some dressed in a way that was too exposing. One of the female respondents, who was a head of department, stated:

There have been complaints on clothes, tight clothes, miniskirts. Pupils yesterday complained that there was whistling. Boys threatened that if that would happen again, they would do something during assembly. Pupils don't want to be led into temptations. Even the male students, they wear jeans, T-shirts, and casual wear. They were even advised not to attend assembly. One male student teacher was wearing a shirt just buttoned halfway. That disturbs a lot. The whole teaching practice period, he was comfortably wearing shirts only buttoned up halfway.

Further, another male respondent, who was a former student at UNZA and a head teacher, asserted that the problem with UNZA teacher education was that it did not teach social skills, while the values and principles guiding the general conduct of a teacher were also left out from the teacher education programs offered at the institution.

Does the Instruction (Content and Methodology) Received from UNZA Adequately Prepare Students for the School Teaching Experience?

Most of the respondents said that the content received was good but not to the expected level. Student teachers said that they had problems knowing how to deliver the content. They said that they knew the methodology and the content exclusively, and they did not know how to systematically present the content, especially within the allocated time. For example, one male student teacher observed, "It was helpful, but not to the level I expected because theory and the practical part of it are very difficult to combine."

Some student teachers said that the methodology was fine but they forgot it because there was a long period from the time they learned it (in the third year) and the time they actually went to school to practice (after the fourth year). They also said that the methodology was weak because there was little time for peer teaching. The respondents said that the methodology would be adequate if they had many contact hours for peer teaching and if the methodology course and teaching practice followed each other successively. One female student teacher said:

In some way, what I learned at UNZA prepared me, but my concern is that most methods courses at UNZA are done in the third year of one's program, but only implemented the following year. 
This is a disadvantage in that students may forget what they were taught in their methodologies. I can also say that methodology is not really adequate because the period of peer teaching was short and happened only once.

Most of the respondents shared the above views, including the school managers, most of whom were graduates from UNZA.

\section{What Are the Challenges Faced in the Design and Delivery of the School Teaching Experience?}

The first challenge that student teachers faced in their placements was a lack of teaching and learning materials. They said that the school libraries did not have the appropriate books that were needed. In one school, there was only one book that all the teachers shared, and the book did not even have all the topics that were required.

In addition, there was no transportation for the student teachers to take to the schools; serving teachers were not cooperative as well. The other challenge that the student teachers faced was classroom management. They attributed it to large classes, which they said were difficult to manage. All the respondents said that there was a lack of discipline in schools, as pupils were rude and uncontrollable. One student teacher said:

There is no discipline in schools. The pupils are very rude, and they make too much noise in class, even when you talk to them. When you punish them, they start calling you names. But the other issue is that there is patronizing. It's like, serving teachers tell pupils not to obey us and just to patronize us.

In addition, student teachers were not offered accommodations by the schools where they were placed. This, coupled with their financial challenges, made their stay during the teaching practicum difficult. Furthermore, those student teachers who learned their content courses from schools of Natural Sciences and Humanities and Social Sciences complained of the difficulty in relating what they learnt in school to the classroom situation when teaching pupils.

\section{Discussion}

Research questions guided the findings in the previous section. This section presents an analysis of the findings. Study objectives will guide the discussion. During discussion, references are made to similar or contrasting findings from other studies done elsewhere within the theme of teacher education and the school teaching experience. At the end of the discussion, a summary is presented.

Objective: To Establish the Effectiveness of the UNZA School Teaching Experience

Some respondents observed that the school teaching experience was effective. However, the school teaching experience is not completely effective. It had a number of weaknesses. One of the reasons why it is not effective is because of the limited time student teachers spent on the practicum. Currently, student teachers are expected to complete the practicum between six and eight weeks. This is the reason why Queensland College (2011) advised that the professional experience of the program should be of a sufficient amount of time to enable all students to develop the required knowledge, skills, and attributes, and to provide adequate opportunities for students to demonstrate the attainment of these against the standards. In addition, Coll and Zegwaard (2006) agree that if students are to develop enthusiasm and be accepted into the chosen profession then they need to spend more time in communities of practice, such as schools.

Further, during coursework at UNZA, students also had little exposure to teaching through peer teaching. Moreover, they report to the school when the term has already commenced. This means that they do not have a complete experience from the start of the term to the end. Cobbold (2011) observed that in many instances in Africa, the timing of the practicum does not allow pre-service teachers to experience school settings from the first day of the new academic year: 
The timing of the practicum denies pre-service teachers the invaluable opportunity to experience the process of setting up a new classroom and how relationships are formed with new groups of school children. (147)

The six week period means that student teachers have little time to do the actual teaching, especially because they spend the first week observing the serving teachers.

Objective: To Establish Student Teachers' Expectations from the UNZA School Teaching Experience

Another objective sought to establish the student teachers' expectations of the school teaching experience. From the findings, the student teachers expected a professional and cordial interaction between themselves and the serving teachers. While some of the serving teachers and school administrators were sociable, others were not, more to the disappointment of the student teachers. According to Queensland College (2011), professional experience should be characterized by collaborative inquiry involving pre-service teachers and site-based teachers in a range of diverse learning contexts. Professional experience should represent a developmental continuum, allowing the pre-service teacher to move from high levels of support to practice which is both autonomous and collaborative. This means that serving teachers should be available to work and help the trainee teachers. In addition, Queensland College (2011) noted that teachers whose classes are allocated to pre-service teachers retain responsibility for the oversight and management of their classes' curriculum and assessment programs. The teaching program planned and implemented by the pre-service teacher is normally limited to a half teaching load.

Surprisingly, some student teachers expected to be given the teaching methods that they would use. This means that the student teachers were not adequately prepared in methodology to deliver the content. With the courses they did in teaching methods, one would expect that they would be able to select and integrate the methods to use for a particular lesson. It appears that the student teachers even had problems with lesson delivery, which in turn implied that UNZA did not adequately prepare student teachers to deliver the lessons in class. These findings agree with Allen and Peach's study (2007), which established that one of the major and longstanding challenges of pre-service teacher education programs has been to strike a balance between the theory and practice of the profession. According to Hartocollis $(2005,2)$, a widely held concern is that "one of the biggest dangers we face is preparing teachers who know theory and know nothing about practice."

UNZA has a weak mode of teacher preparation, which affects student teachers negatively when the government deploys them to go and teach in classrooms. Coll and Zegwaard (2006) point out that the changing nature of the world of work and the capacity of universities to prepare adaptable and innovative graduates is a concern to government. They add that there is an urgent need to try to understand the future workplace into which graduates will emerge and the skills that will be required.

Teacher education studies attest to a disparity between the theory presented in pre-service programs and practice in the workplace (Cochran-Smith 2005; Neville et al. 2005; Liston et al. 2006). Critics of teacher education are quick to point out deficiencies in program design and delivery when it appears that theoretical knowledge and understandings have been prioritized over learning practical skills (Liston et al. 2006).

Objective: To Establish Student Teachers' Expectations from School Teaching Experience Supervisors (Lecturers)

The third objective was to establish the student teachers expectations from UNZA lecturers. Student teachers expected lecturers to be in contact with them and to be available for consultation during the practicum. However, lecturers did not make themselves available and accessible to student teachers throughout the teaching experience period as their perceived interest was just in classroom observation. This is in agreement with Mannathoko (1999) 
who noted that in Botswana, channels of communication were poor between the student teaching office and the schools and that there was need for a more structured program for working with schools, especially to develop rapport with schools and teachers. This is the reason why Mannathako (1999) advised that channels of communication are supposed to be improved on, both within and outside the schools of education. This is because early research on university supervision found some positive effects on student teachers' performance, critical reflection, and attitudes (McIntyre et al. 1996).

More recent literature demonstrates a positive impact of university supervisors on student teachers' pedagogy, classroom management, autonomy, and efficacy. Increased frequency of supervision has also been shown to predict teachers' planned persistence and effectiveness (Oh et al. 2005; Boyd et al. 2009). This is the reason why university supervisors should always be available to students during the practicum.

\section{Objective: To Establish Student Teachers' Expecta- tions from Cooperating Schools}

The fourth objective was to establish the student teachers' expectations from the cooperating schools. Like was the case with expectations from the teachers, the student teachers expected cooperation. For example, they expected to consult the teachers and plan their lessons together. However, in most cases, the teachers were not available for consultation and did not encourage working as a group. Many have suggested that cooperating teachers, more than other figures, have the strongest influence on pre-service teacher attitudes and learning during student teaching, and perhaps across teacher preparation generally (Karmos and Jacko 1977; Manning 1977; Smagorinsky et al. 2006; Cook 2007).

Serving teachers have stereotyped UNZA students as knowing everything, so they withhold help or guidance. The most important thing they seem to forget is that student teachers who go for practicum are students and that the practicum is part of the learning process. In addition, they do not realize that they have a vital role to play in teacher preparation.
That is why Queensland College (2011) advised that professional experience should be characterized by collaborative inquiry involving pre-service teachers and site-based teachers in a range of diverse learning contexts.

The professional experience should represent a developmental continuum. This means that sitebased teachers should look at trainee teachers not only as teachers but also as people and students who are in the process of becoming teachers.

Part of the reason for the apathy that student teachers experience in their placements is because they (the schools) are not included in the design and delivery of the school teaching experience, so they do not fully understand their role in teacher preparation. It is important that teachers and school administrators change their attitudes. This is because their attitude is against the expectation of UNZA, which expects them to have a good working relationship with the student teachers.

\section{Objective: To Establish UNZA Lecturers' Views on the School Teaching Experience}

It can be noted from the findings that the lecturers agreed with the teachers as well as the student teachers that the school teaching experience was not well designed. It did not correspond with the high schools' academic calendar. In addition, lecturers also acknowledged that they did not communicate with students. As a result, lecturers sometimes visited schools to observe students and found that students were not prepared because they were not communicated to in advance.

This situation is in agreement with student teachers who complained that lecturers did not communicate with them effectively. They pointed out that the only communication was when a particular lecturer was going to observe them. This is also in agreement with the situation in Botswana, as noted by Mannathoko (1999) who observed that in Botswana, channels of communication were poor between the student teaching office and the schools, and that there was a need for a more structured program for working with schools, especially to develop a rapport between schools and teachers. 
Objective: To Establish the Cooperating Partners' Views on the UNZA School Teaching Experience

The views of the cooperating schools were very similar to those of the lecturers as well as the student teachers. For example, the observation that the period for the practicum was very short and student teachers were not adequately prepared in methodology and professionalism. The practicum at UNZA took six weeks. On the contrary, Matthew Ronfeldt and Michelle Reininger (2012), reported that in the United States, student teaching is usually a semester in length (12-15 weeks), though this varies by institution, certification level (elementary or secondary), degree type (undergraduate or postgraduate), and preparation route (alternative or traditional). Findings from the above study shows that the practicum at UNZA is shorter than it actually should be.

The cooperating schools complained about the behavior of some of the students and observed that some student teachers were for example not properly dressed. This implies that UNZA does not focus much on teaching ethics and desirable behavior to students. This view is in agreement with Allen and Peach (2007) who observed that in Australia, behavior management was not listed as one of the primary learning targeted by the university. Our findings are also in line with Manchishi and Masaiti (2011) who noted that UNZA did not focus on teachers' professional ethics.

Objective: To Establish Whether the Instruction (Content and Methodology) Student Teachers Receive from UNZA Is Adequate to Prepare Them for the School Teaching Experience

Another objective was to establish if the instruction received at UNZA adequately prepared students for the teaching experience. While some students said that it was adequate, most of them said that it was not adequate. Those who said that it was not adequate agreed with lecturers and cooperating schools who observed that student teachers were not adequately prepared.

There is another view that student teachers were well prepared in subject content but ill prepared in methodology. For example, it has been reported that university teacher programs have not provided enough preparation for the teaching practicum.

Teacher education studies attest to a disparity between the theory presented in pre-service programs and practice in the workplace (Cochran-Smith 2005; Neville et al. 2005; Liston et al. 2006). Hence, critics of teacher education are quick to point out deficiencies in program design and delivery when it appears that theoretical knowledge and understandings have been prioritized over learning practical skills (Liston et al. 2006).

Therefore, the real problem was not the knowledge of the subject content but the methodology to teach the content. However, the study has also shown that while the students receive a lot of content, the content they receive is not tailored to teaching. This obviously makes it hard for the students, as they have to relate the content to teaching on their own. Allen and Peach (2007) reported that in Australia, several participants clearly valued the practical experience acquired during the practicum experience over the theoretical component of their training in the university. According to one student, skills taught at university are "just imagined and planned for" while the practicum was "real life practice." Therefore, it is generally felt that the instruction received particularly in methodology was not adequate and classroom related.

This finding is in agreement with Manchishi and Masaiti (2011) who noted that there was a gap between what students learned on campus and what was being obtained in schools. In view of the above observation, there is need to re-look at the content at UNZA and tailor it towards teaching.

Objective: To Establish the Challenges Faced in the Design and Delivery of the School Teaching Experience

The final objective was to establish the challenges experienced during the teaching practice. The study revealed that challenges included lack of teaching and learning materials, discipline issues among pupils, transportation to and from schools, lack of financial support, lack of cooperation from serving 
teachers, lack of knowledge on how to handle disabled children, lack of accessibility to UNZA lecturers, lack of knowledge of sign language, and early reporting for work.

In line with the financial challenges, it must be mentioned the financial challenge is for both universities and individual students. On the part of the university, Queensland College (2011) also listed the cost of delivery as the first challenge. Within the constraints of limited institutional budgetary allocations for the teaching practicum, it has become increasingly difficult to adequately remunerate university and school-based supervisors and meet the high administrative costs associated with the practicum.

The challenges presented above suggest that UNZA lecturers, the student teaching office, student teachers, and cooperating schools have to work hard individually and collectively if the school teaching experience is to be effective. For example, student teachers complained that they were asked to report for work very early even if they did not have an early class. This complaint is due to ignorance on the part of student teachers; they should be taught that professionally and ethically, they need to report for work at a certain time whether or not they have a class.

Secondly, lack of teaching and learning materials have been a perpetual problem in schools. It is important that government and schools work hand in hand to make sure that each school is stocked with the necessary books. The financial challenges for students who are government sponsored is partly because they are given project money way before the practicum. This means that by the time they go for practicum, the money is finished and they end up starving or eating with the students. It is important that the project allowance is given to student teachers at the time when they are going for practicum. In fact, there should be an allowance specifically for the purpose of teaching practice.

The other challenge was lesson planning and knowing which methods to use. This was because of inadequate preparation at UNZA, as well as a lack of assistance from the serving teachers. Commenting on the difficulty of the student teachers to adapt to teaching in the classroom, Machishi and Masaiti (2011) noted that "UNZA trained teachers had difficulties in delivery and also adjusting to high school syllabus."

\section{Summary of Objectives}

It is clear from the findings and discussion of the findings that the UNZA school teaching experience is not very effective in the current format. While the content of the subjects is adequate, the methodology courses do not address a wide range of pedagogical aspects. The period of the practicum is short, there is poor communication between supervisors (lecturers) and the student teachers, the student teachers and the serving teachers do not collaborate adequately, and the student teachers also fail to adjust to the school and personnel within the placement area. Further, the teacher education program at UNZA does not include some important aspects, such as social skills and ethics guiding the teaching profession.

\section{Conclusion and Recommendations}

The findings have shown that the UNZA student teaching experience was not very effective because the period was too short, the lecturers and the teachers were not helpful, and the instruction received (content and methodology) was not adequate to prepare the student teachers for the teaching experience. It was further established that most of the content received from UNZA was not classroom-tailored, which made it very difficult for student teachers to relate the content to the classroom situation at the level of the pupils they taught. Student teachers expected cooperating schools and head teachers to be cooperative and to be available for consultation. They also expected UNZA lecturers to be in constant communication with them and provide them with the guidance they needed.

Unfortunately, most of their expectations were not met, as teachers from cooperating schools were not available for consultation and UNZA lecturers only got in touch with the student teachers when they wanted to go and observe them. In short, the 
design and delivery of the UNZA school teaching experience was not well done and needed a lot of improvement.

Based on the findings and conclusions above, the following recommendations can be made. First, the school teaching experience office should start holding workshops and seminars with cooperating schools to explain the purpose of the school teaching experience and what is expected of the cooperating school and the serving teachers during the practicum. Second, the School of Education, through the school teaching experience, should be holding sessions to talk to students about what is expected of them during the teaching practice and include professional ethics in the teaching methodology courses. Third, the School of Education should develop a system where each lecturer should have a group of students that he or she would be mentoring from the first year until the fourth year. Fourth, the school teaching experience should be graded just like any other course. Finally, the school teaching experience period should be extended, and it should be conducted at the end of third year of study.

\section{References}

Allen, Jeanne Maree, and Deborah Peach. 2007. "Exploring Connections Between the In-Field and On-Campus Components of a Pre-Service Teacher Education Program: A Student Perspective." Asia-Pacific Journal of Cooperative Education 8 (1): 23-36.

Boud, David, Nicky Solomon, and Colin Symes. 2001. "New Practices for New Times." In Workbased Learning: A New Higher Education? ed. David Boud and Nicky Solomon (pp. 3-17). Buckingham, UK: The Society for Research into Higher Education \& Open University Press.

Britzman, Deborah P. 1991. Practice Makes Practice: A Critical Study of Learning to Teach. Albany, NY: State University of New York Press.

Britzman, Deborah P. 2003. Practice Makes Practice: A Critical Study of Learning to Teach (Revised Edition). Albany, NY: State University of New York Press.
Chakalisa, Paul A. 1990. "University of Botswana Teaching, Practice, Planning, Supervision and Related Issues." In Visions of Teacher Education in Southern Africa, The Botswana Experience, ed. Changu Mannathoko and Cephas David Yandila. Gaborone, Botswana: University of Botswana.

Cobbold, Cosmas. 2011. "Improving the Practical Aspect of Pre-Service Teacher Education in Sub-Saharan Africa: Issues of Conceptualization, Planning and Management." Academic Leadership 9 (1).

Cochran-Smith, Marilyn. 2005. "Studying Teacher Education: What We Know and Need to Know." Journal of Teacher Education 56 (4): 301-307.

Coll, Richard K., and Karsten E. Zegwaard. 2006.

"Perceptions of Desirable Graduate Competencies for Science and Technology New Graduates." Research in Science \& Technological Education 24 (1): 29-58.

Cook, Lysandra. 2007. "When in Rome: Influences on Special Education Student Teachers' Teaching." International Journal of Special Education 22 (3): 119-130.

Danielson, Charlotte. 2008. A Handbook for Enhancing Professional Practice. Alexandria, VA: Association for Supervision and Curriculum Development.

Darling-Hammond, Linda. 2006. Powerful Teacher Education. San Francisco, CA: Jossey-Bass.

Ducharme, Edward R., and Mary K. Ducharme. 2005. "Teacher Educators and Teachers: The Needs for Excellence and Spunk." In The Role of the University in the Preparation of Teachers, ed. Richard R. Roth (pp. 39-56). Palmer Press: London.

Gandhe, S. K. 2010. "Teacher Professional Development in India." Paper presented at PCF6, Kochi, India, November.

Haberman, Martin. 1991. "The Rationale for Training Adults as Teachers." In Empowerment Through Multicultural Education, ed. Christine E. Sleeter (pp. 275-286). Albany, NY: State University of New York Press.

Harrison, Lorraine. 2004. "Qualified Teacher Status." In Professional Standards for Teacher and School Leaders, ed. Howard Green (pp. 63-78). New York, NY: Routledge Falmer. 
Hartocollis, Anemona. 2005. "Who Needs Education Schools?" New York Times, July 31.

Henke, Robin R., Xianglei Chen, and Sonya Geis. 2000. Out of the Classroom and into the Lecture Hall: 1992-1993 College Graduates and Elementary/Secondary School Teaching. Washington, DC: National Center for Education Statistics.

Ingvarson Lawrence, Adrian Beavis, Elizabeth Kleinhenz, and Allison Elliott. 2004. Pre-Service Teacher Education in Australia: A Mapping Study of Selected Processes, Course Structure and Context, and Accreditation Process. Australian Council for Educational Research. Available online at: http://research.acer.edu.au/teacher_education/3.

Jerome, Lee, Jeremy Hayward, and Helen Young. 2003. "Professional Development in Citizenship Education." In Learning to Teach Citizenship Education in the Secondary School, ed. Liam Gearon (pp. 203-224). New York, NY: Routledge Falmer.

Karmos, Ann H., and Carol M. Jacko. 1977. "The Role of Significant Others During the Student Teaching Experience." Journal of Teacher Education 28 (5): 51-55.

Korthagen, Fred, John Loughran, and Tom Russell. 2006. "Developing Fundamental Principles for Teacher Education Programs and Practices." Teaching and Teacher Education 22 (8): 1020- 1041.

Korthagen, Fred, and Kessels, Jos. 1999. "Linking Theory and Practice: Changing the Pedagogy of Teacher Education." Educational Researcher 28 (4): 4-17.

Lecha, M. 1990. "Some Practical Issues About Teacher Preparation." In Visions of Teacher Education in Southern Africa, The Botswana Experience, ed. Changu Mannathoko and Cephas David Yandila. Gaborone, Botswana: University of Botswana.

Liston, Daniel, Jennie Whitcomb, and Hilda Borko. 2006. "Too Little or Too Much: Teacher Preparation and the First Years of Teaching." Journal of Teacher Education 57 (4): 351-359.

Manchishi, Peter Chomba. 2013. Reforming Zambian Pre-Service Teacher Education for Quality Learning. Lusaka, Zambia: University of Zambia.
Manchishi, Peter Chomba, and Gift Masaiti. 2011. "The University of Zambia Pre-Service Teacher Education Programme: Is It Responsive to Schools and Communities?" European Journal of Education Studies 3 (2): 311-324.

Mannathoko, Magdeline C. 1989a. A Formative Evaluation of Teaching Practice in Botswana Secondary Schools. Gaborone, Botswana: University of Botswana.

Mannathoko, Magdeline C. 1989b. Teaching Practice Handbook. Gaborone, Botswana: University of Botswana.

Mannathoko, Magdeline C. 1990. Coordination of Teaching Practice at University of Botswana. Gaborone, Botswana: University of Botswana.

McIntyre, D. John., David Byrd, and S.M. Foxx. 1996. "Field and Laboratory Experiences." In Handbook of Research on Teacher Education, ed. John Sikula (pp. 171-193). New York, NY: Macmillan.

McManus, Chris. 2002. Right Hand, Left Hand: The Origins of Asymmetry in Brains, Bodies, Atoms and Cultures. Cambridge, MA: Harvard University Press.

Mulomo, R. 1990. "Official Opening Speech at the First National Conference on Teaching Practice." In Visions of Teacher Education in Southern Africa, The Botswana Experience, ed. Changu Mannathoko and Cephas David Yandila. Gaborone, Botswana: University of Botswana.

Munby, Hugh, Tom Russel, and A. Martin. 2001. "Teacher's Knowledge and How It Develops." In Handbook of Research on Teaching, ed. Virginia Richardson (pp. 877-880). Washington, DC: American Educational Research Association.

Musonda, Lawrence. 1995. "A Case Study of the University of Sussex Primary PGCE Course Teaching Experience." Master diss., University of Sussex.

Oh, Deborah M., Anne M. Ankers, Joseph M. Llamas, and Catherine Tomyoy. 2005. "Impact of Pre-Service Student Teaching Experience on Urban School Teachers." Journal of Instructional Psychology 32 (1): 82-98.

Ronfeldt, Matthew, and Michelle Reininger. 2012. "More or Better Student Teaching?" Journal of Teaching and Teacher Education 28 (8): 1091-1106. 
Queensland Government. 2011. Program Approval Guidelines for Pre-service Education. Brisbane, Austrailia: Queensland Government.

Schulte, Ann Katherine. 2010. Seeking Integrity in Teacher Education. Chico, CA; Springer.

Smagorinsky, Peter, Amy Davis Sanford, and Bonnie Konopak. 2006. "Functional Literacy in a Constructivist Key: A Non-traditional Student Teacher's Apprenticeship in a Rural Elementary School." Teacher Education Quarterly 33 (4): 93109.

Smith, Kari, and Lilach Lev-Avri. 2005. "The Place of the Practicum in Pre-service Teacher Education: The Voice of the Students." Asia-Pacific Journal of Teacher Education 33 (3): 289-302.

Smith, Richard, and Teresa Moore. 2006. "The Learning Management Concept." In The Rise of the Learning Manager: Changing Teacher Education, ed. Richard Smith and David Lynch. Freschs Forest, New South Wales: Pearson.

Sockett, Hugh T., Elizabeth K. DeMulder, Pamela C. LePage, and Diane R. Wood. 2001. Transforming Teacher Education: Lessons from Professional Development. London: Praeger.

Tabachnick, B. Robert, Thomas S. Popkewitz, and Kenneth M. Zeichner. 1979-1980. "Teacher Education and the Professional Preparation of Student Teachers." Interchange 10 (1): 12-29.

White, C.J. 2003. Research Methods and Techniques. Pretoria, South Africa: Mustung.

Youngman, Frank. 1995. "Welcoming Address at the First National Conference on Teaching Practice." In Visions of Teacher Education in Southern Africa, The Botswana Experience, ed. Changu Mannathoko and Cephas David Yandila. Gaborone, Botswana: University of Botswana.

Zeichner, Ken. 1996. "Designing Educative Practicum Experiences for Prospective Teachers." In Currents of Reform in Pre-service Teacher Education, ed. Kenneth M. Zeichner, Susan Melnick, and Mary Louise Gomez (pp. 215-233). New York, NY: Teachers College Press. 